\title{
APLIKASI HERMENEUTIKA DALAM FIQH PEREMPUAN (Studi Pemikiran Khaled Abou el Fadl tentang fiqh Perempuan dalam Fatwa CRLO)
}

\author{
Iman Fadhilah \\ Universitas Wahid Hasyim Semarang \\ Email: iman_fadhilah@yahoo.co.id
}

\begin{abstract}
Abstrak
Evolusi konsep fiqh yang masih sering dipermasalahkan adalah tentang "fiqh perempuan". Selama ini, product fiqh dianggap diskriminatif, tidak menghargai hak-hak perempuan bahkan terkesan melecehkan perempuan, ayat-ayat tentang waris, kesaksian dan wali banyak disinyalir hanya mengunggulkan kaum laki-laki. Dari segala lini kehidupan, proses metamorfosis fiqh mulai terasa, terlebih di abad modern sekarang ini. Dengan pesatnya ilmu pengetahuan dan teknologi maka isuisu persamaan hak, kebebasan, keadilan gender dan lain-lain terus menggejala di berbagai belahan dunia. Pemikiran Khaled Abou el Fadl telah melihat mekanisme perumusan dan pengambilan keputusan fatwa-fatwa yang dikeluarkan baik oleh pribadi-pribadi, tokoh-tokoh masyarakat dan lebih-lebih lembaga-lembagaa dan organisasi keagamaan pada umumnya. Salah satu kritik Khaled Abou el Fadl tentang fiqh perempuan adalah kritik dari fatwa yang dikeluarkan oleh CRLO yang cenderung mendiskriminasikan perempuan dalam berbagai aktivitas kehidupannya. Dalam konteks tersebut, pada dasarnya hal yang terpenting untuk dipahami dalam hermeneutik adalah bagaimana sesungguhnya hubungang teks (text) atau nash, penulis atau pengarang (author) dan pembaca (reader) dalam dinamika pergumulan pemikiran hukum Islam. Dengan demikian hal yang diperlukan adalah fiqh yang humanis dan tidak diskriminatif terhadap perempuan.
\end{abstract}

Kata kunci: Hermeneutika, fiqh, perempuan

\begin{abstract}
The evolution of fiqh concept which still questionable is about "women fiqh". During this time, fiqh product is considered discriminative, not respect to the women rights and even impressed harassed the women, verses about inheritance, testimony and trustee many allegedly only favor the men. By from all life aspects, the process of fiqh metamorphosis begin to feel, especially in modern century. By the rapid development of science and technology, issues of equality, freedom, justice, gender and etc keeps implicated in various parts of the world. Khaled Abou el Fadl's thought has seen the formulation mechanism and decision making of the (fatwa2) issued by personal, public figures, and even religius foundation and institutions in general. One of Khaled Abou el Fadls critics about the women fiqh is a critic from (fatwa) issued by CRLO that tend to discriminate the women in their various life activities. In that context, basically the most important thing to understand in hermeneutics is how the written text (text) or script, the writer or authors and the readers in dynamics of the struggle
\end{abstract}




\section{Iman Fadilah}

of Islamic legal thought. Thus the things needed is humanist fiqh and discriminative against the women

Keywords: hermeneutics, fiqh, woman

\section{A. Pendahuluan}

Dalam Islam, al-Qur'an sebagai sumber dan pegangan hidup umatnya ternyata di dalamnya banyak mengandung ayat-ayat yang mengatur hubungan antara perempuan dan laki-laki (ayat-ayat nisaiyyah-yang "disinyalir tidak seimbang"). ${ }^{1}$ Contoh tentang kepemimpinan perempuan, bahwa seorang perempuan masih tidak diperbolehkan menjadi pemimpin, padahal dalam surat an-Nisa:1 diterangkan bahwa hak laki-laki dan perempuan adalah sama. ${ }^{2}$

Disadari atau tidak, fiqh terus bersinggungan dengan kondisi dan konteks masyarakat yang berbeda dengan sebelumnya. Tidak mengherankan, masyarakat mulai kritis terhadap perkembangan fiqh yang dirasa mulai ada kesimpangsiuran untuk beradaptasi dengan kondisi zaman yang terus-menerus mengalami pergeseran. Artinya, bahwa fiqh harus terus relevan dan seimbang dengan setting sosial masyarakat karena tidak semua produk fiqh dapat diterapkan untuk semua zaman seiring dengan dinamika perkembangan zaman, fiqh terus menerus mengalami metamorfosis, hanya saja dalam fase-fase tertentu terkadang mengalami "kejumudan". Diantara evolusi konsep

\footnotetext{
${ }^{1}$ Syahrur melihat bahwa lafad an nisa berasal dari kata Annasi'ah yang berarti hasil usaha, al mutaakhar; yang datang terlambat, dan almustajid yang baru didapatkan. Muhammad Syahrur dilahirkan di Damaskus, Syiria pada 11 April 1938. Sejak 1969 ia mengajar di Fakultas Teknik Sipil Universitas Damaskus. Ia meraih gelar doktor pada tahun 1972 dengan spesialisasi mekanikan pertahanan dan fondasi. Diantara pemikir kontemporer, Syahrur adalah salah satu pemikir yang meneriakkan perlunya pembaharuan dan peninjauan kembali pemikiran Islam. Ia disejajarkan dengan tokoh-tokoh kontemporer seperti Arkoun, Al Jabiri, Abu Zaid, Hasan Hanafi, An Naim dan lain-lain.

${ }^{2}$ Lihat QS an Nisa ayat I yang artinya: Hai sekalian manusia, bertakwalah kepada Tuhanmu yang telah menciptakan kamu dari seorang diri dan daripadanya. Allah menciptakan isterinya dan daripada keduanya Allah memperkembangbiakkan laki-laki dan perempuan yang banyak. Dan bertakwalah kepada Allah yang dengan (mempergunakan) nama-Nya kamu saling meminta satu sama lain dan peliharalah hubungan satu silaturrahim. Sesungguhnya Allah selalu menjaga dan mengawasi kamu.
} 


\section{Iman Fadilah}

fiqh yang masih dianggap "jumud", dipermasalahkan adalah tentang "fiqh perempuan". Selama ini, product fiqh dianggap diskriminatif, tidak menghargai hak-hak perempuan bahkan terkesan melecehkan perempuan, ayat-ayat tentang waris, kesaksian dan wali banyak disinyalir hanya mengunggulkan kaum laki-laki.

Dari segala lini kehidupan, proses metamorfosis fiqh mulai terasa. Terlebih di abad modern sekarang ini, dengan pesatnya ilmu pengetahuan dan teknologi. Isu-isu persamaan hak, kebebasan, keadilan gender dan lain-lain terus menggejala di seantero dunia. Dan ini sangat erat hubungannya dengan perkembangan fiqh Islam. Artinya, sekarang sangat diperlukan fiqh yang humanis dan tidak diskriminatif. Salah satu fiqh yang dianggap tidak adil adalah dalam masalah persamaan hak antara perempuan dan laki-laki sebagaimana di terangkan di atas.

Al-Qur'an sebagai salah satu sumber pokok fiqh seolah menempatkan kedudukan laki-laki di atas perempuan. Tentang waris, kesaksian kepemimpinan dan lain-lain. Kesemuanya memposisikan wanita sebagai sub ordinasi dari laki-laki. Perebutan wacana tentang perempuan pada hakekatnya adalah membicarakan bagaimana fiqh ke depan. Apakah fiqh sekarang masih relevan? Tentang aqiqoh misalnya, yang mengharuskan untuk bayi laki-laki dua ekor kambing dan untuk bayi perempuan hanya satu. Dalam persaksian wanita nilainya separo dari laki-laki. Sama ketika seseorang mati, kalau yang mati laki-laki maka pihak keluarga menuntut 100 ekor unta. Sedangkan jika yang terbunuh adalah wanita maka tuntutan hanya 50 ekor unta. begitupun dengan harta warisan, bagian perempuan hanya setengah dari bagian laki-laki. Kalau kita teliti konsep fiqh yang demikian sangat bertentangan dengan konsep kesetaraan, dan persamaan dan keadilan baik pria mauapun wanita dalam Islam. 


\section{Iman Fadilah}

Begitupun kitab-kitab hadits, dalam masalah waris sejauh ini jarang bahkan tidak ada yang memuat asbab an nuzul yang berkenaan dengan waris (QS 4;8). Tabari (w.923) merekam tiga asbab an nuzul yakni dari Qatadah yang dianggap pernah berkata "kebiasaan mereka untuk tidak memberikan warisan kepada para wanita". Maka turunlah ayat "Dan bagi wanita ada hak dari warisan peninggalan ibu bapak dan kerabat". Pernyataan semisal dinisbatkan kepada ibnu Zaid (w.798) "Semasa jahiliyyah para wanita tidak mewarisi berdasarkan peristiwa diatas maka turunlah surat 4:8.

Melihat al-Qur'an surat an Nahl: 97.3 Allah berjanji akan memberikan balasan yang setimpal baik bagi laki-laki ataupun perempuan yang melakukan amal sholeh. Pada sisi ini juga kita perlu menganalisis kembali antara konsep fiqh yang dianggap zhanny dan sifatnya teknis operasional, sesuai dengan seting sosial masa itu. Artinya ada ajaran yang tidak bisa diubah adalah ajaran yang sifatnya mutlak dan qot'iy. Hanya saja belum ada pembagian lahan yang jelas antara mana-mana yang termasuk ajaran qatiyyuddalalah dan manasaja yang termasuk ajaran yang zhanni.

Mencermati Surat al-Hujurat ayat 14 yang artinya "Sesungguhnya telah aku ciptakan laki-laki dan perempuan dan aku jadikan kalian berbangsa dan bersuku-suku agar kalian lebih saling mengenal sesungguhnya yang paling mulia diantara kalian adalah yang paling taqwa". Hal yang sama dijelaskan dalam surat at-Taubah ayat 71, an-Nisa ayat 123, surat ali Imron ayat 195 dan an-Nahl 97. Bahwa pada hakikatnya Islam meletakkan perempuan dalam posisi yang seimbang (QS al-Baqarah: 182) "hunna libassullakum waanta libasun

\footnotetext{
${ }^{3}$ Artinya; Barangsiapa yang mengerjakan amal saleh, baik laki-laki maupun perempuan dalam keadaan beriman, Maka Sesungguhnya akan kami berikan kepadanya kehidupan yang baik[Ditekankan dalam ayat Ini bahwa laki-laki dan perempuan dalam Islam mendapat pahala yang sama dan bahwa amal saleh harus disertai iman] dan Sesungguhnya akan kami beri balasan kepada mereka dengan pahala yang lebih baik dari apa yang Telah mereka kerjakan.
} 


\section{Iman Fadilah}

lahunna". Juga dalam sistem hukum, Islam menyamakan lelaki dan perempuan tanpa memandang perbedaan yang ada, baik itu fisik (QS An-Nazm: 45), (QS ad-Dariyyat: 49), maupun perbedaan kemampuan akal (Qs al-Hujurat: 13) dan (QS al-Isro: 70).

Jadi sangat diperlukan mafhum an-nash-meminjam istilah Nasr Hamid Abu Zayd dan reinterpretasi dari ayat-ayat tentang perempuan. Terlebih ayat-ayat itu bersifat zanny, temporal sesuai dengan kondisi masyarakat di mana ayat itu diturunkan. Banyaknya keterangan, riwayat dan asbab-al nuzul adalah salah satu buktinya yang tidak kalah pentingnya adalah harus diadakannya reformasi terhadap sistem masyarakat yang bias patriarkhi dan mengarah kepada ketidakadilan gender.

Solusi yang tepat yaitu harus diadakan reinterpretasi al-Qur'an yang selama ini dianggap mengandung bias patriarkhi yang cenderung merugikan perempuan. Sedangkan untuk melakukan reinterpretasi yang sensitif gender mau tidak mau metode penafsiran juga harus direkonstruksi. Sebab ketika metodologinya sudah bias gender, maka hasil penafsirannyapun juga akan bias gender. Diantara metodologi yang dianggap bias gender menurut Nasarudin Umar adalah metodologi tafsir tahlili atau tajzi'i, yang cenderung menafsirkan secara sepotong-sepotong atau parsial. Salah satu contoh, ketika mufasir mencoba untuk memahami ayat-ayat tentang poligami. Metode tahlili terkesan mempermudah untuk mengijinkan seorang untuk berpoligami dengan syarat adil.

Salah satu metode yang (agak) tepat adalah metode maudlui atau tematik (holistik), yang mencoba menafsirkan ayat tentang poligami, maka kesimpulannya adalah sangat tidak dimungkinkan seseorang bisa berbuat adil dalam kondisi yang seperti itu. Misalnya bisa dilihat dalam surat an-Nisa ayat 129, artinya "Dan kalian sekali- 


\section{Iman Fadilah}

kali tidak akan berlaku adil diantara istri-istrimu". Sebagaimana disebutkan di atas, yang harus dicermati adalah bahwa sebagai produk ijtihad, fiqh masih sangat tergantung dari siapa perumusnya termasuk subjektifitas perumus, apalagi sampai hari ini, sedikit sekali bahkan jarang buku fiqh yang menyertakan bantalan metodologi dan epistemologinya secara lengkap. Harus diakui, sebagian besar fiqh masih ittiba terhadap metodologi atau manhaj yang telah dikerangkakkan oleh para imam madzhab. Yang jadi persoalan adalah ruang di mana fiqh itu diciptakan dengan kondisi sosial ekonomi yang melingkupinya, lokus geografis, epistemologi apa yang dipakai, sangatlah berpengaruh terhadap proses pembentukan fiqh tersebut, termasuk dalam fiqh perempuan.

\section{B. Pembahasan}

\section{a. CRLO dan Fatwa tentang perempuan}

Dalam konteks Indonesia, lembaga fatwa keagamaan bukanlah hal yang baru. Beberapa Ormas (organisasi kemasyarakatan) di Indonesia memiliki lembaga fatwa. Misalnya Muhammadiyah memiliki Majelis Tarjih, Nahdlatul Ulama (NU) memiliki Lembaga Bahtsul Masail, ada Dewan Hisbah dan juga Komisi Fatwa MUI. Tidak jauh berbeda, di Arab Saudi ada lembaga fatwa keagamaan yang disebut CRLO (Council for Scientific Research and legal Opinion) atau "al Lajnah al Daimah li al buhuts al ilmiyyah wa al ifta'.

Berbagai fatwa keagamaan telah dikeluarkan oleh CRLO diantaranya tentang hukum perempuan mengenakan bra, perempuan yang mengemudikan mobil, suami yang menyusu, perempuan yang membatalkan shalat seorang laki-laki, pentingnya menikah versus pentingnya pendidikan bagi perempuan, pernikahan dengan niat bercerai, perempuan yang menjadi penghuni neraka terbanyak, membuka hijab karena alasan medis, perempuan yang diciptakan dari 


\section{Iman Fadilah}

tulang rusuk yang bengkok, pembawa sial, perempuan yang lemah akal dan agamanya, larangan foto, kesabaran menanggung perlakuan buruk suami, ketaatan pada suami, larangan melakukan ziarah kubur bagi perempuan, pembauran antara laki-laki dan perempuan, hukum perempuan yang bekerja, bahaya bagi perempuan yang bekerja bersama laki-laki.

Dalam tubuh CRLO ada yang disebut komite CRLO yang diketuai oleh Ibn Baz. Diantara anggota CRLO adalah al Usaymin, Shalih In Fawzan, Ibnu Jibrin dan Abdul Rozak Afifi. Pada prakteknya, CRLO membuat majelis untuk merumuskan secara bersama fatwa keagamaan yang menjadi permasalahan yang terjadi di Arab. Para anggota CRLO ini senantiasa mengamati persoalan keagamaan di Arab Saudi sebagai bagian dari tugas mereka untuk selanjutnya dibuatkan fatwa keagamaan sebagai pedoman bagi masyarakat Arab Saudi. Sekalipun fatwa tersebut tidak mengikat, akan tetapi cukup membawa pengaruh dalam penerapan hukum Islam di Masyarakat. Kumpulan fatwa keagamaan hasil putusan dari CRLO ini kemudian dibukukan menjadi beberapa bagian. Misalnya Ibnu Baz mengumpulkan hasil fatwanya dalam Majmu fatawa wa Maqalat Mutanawwi'ah (1990). Shalih Ibn Fauzan, kitabnya al Muntaqa. Ibnu Jibrin kitabnya fatawa al Lajnah dan Abdul Razak Afifi dengan Warailnya.

\section{b. Fatwa-fatwa CRLO}

Dalam fatwa al Lajnah (Ibnu Jibrin menghimpun fatwa-fatwa hasil dari kesepakatan CRLO yang berasal dari pertanyaan masyarakat (Ibn Jibrin: 205), diantaranya:

\section{Tentang hukum menggunakan bra}

Pertanyaan: Bagaimana hukumnya perempuan yang menggunakan bra? 


\section{Iman Fadilah}

Fatwa: beberapa perempuan telah membiasakan diri mereka untuk mengangkat payudara mereka dan menopangnya dengan sepotong kain dengan maksud agar terlihat lebih muda atau tampak seperti perawan atau semisalnya. Jika hal tersebut dilakukan untuk tujuan seperti itu maka ia (yaitu mengenakan bra) dipandang sebagai bentuk pengelabuan yang tidak dibenarkan namun jika hal tersebut dilakukan untuk mencegah cedera tertentu atau menghindari penyakit atau hal serupa maka ia diperbolehkan sesuai dengan keperluan (mengenakan bra) dan Tuhan tahu yang terbaik. ${ }^{4}$

Fatwa ini di himpun langsung oleh Ibnu Jibrin dalam al Fatawa al Lajnah (2005). Dalam fatwa ini Ibnu Jibrin menggunakan landasan hadits "siapapun yang berlaku curang bukanlah kelompok kami". Selain ibnu Jibrin, fatwa ini juga dihimpun oleh al Utsaymin dalam kitabnya fatawa al Utsaymin. CRLO memandang bahwa perempuan yang memakai bra berdasar hadits di atas adalah masuk kategori curang karena berniat memamerkan keindahan bentuk tubuh.

\section{Tentang pernikahan dengan niat bercerai}

Pertanyaan: saya mendengar salah satu fatwa anda dalam kaset rekaman bahwa anda memperbolehkan pernikahan yang dilangsungkan diluar negeri, dan si laki-laki yang menikahi si perempuan berniat akan menceraikannya setelah masa kerja atau studinya berakhir. Bila demikian halnya apa yang membedakan nikah tersebut dengan nikah kontrak yang dilarang? Apa yang harus dilakukan jika istrinya melahirkan seorang anak perempuan? Apakah ia harus meninggalkannya di negeri tersebut bersama mantan istrinya? Saya perlu penjelasan anda. Fatwa: betul, CRLO yang saya ketuai telah mengeluarkan sebuah fatwa mengenai pernikahan yang dilakukan dengan niat bercerai selama niat tersebut dirahasiakan antara

\footnotetext{
${ }^{4}$ Terjemahan dari Fatwa asli Ibnu Jibrin.
} 


\section{Iman Fadilah}

mempelai laki-laki dan Tuhan. Jika ia menikah di luar negeri degan niat akan menceraikan istrinya setelah selesai masa kerja atau studinya, ia dinilai tidak bersalah menurut mayoritas ulama. Lebih jauh lagi niat semacam itu tidak dijadikan persyaratan dalam akad pernikahan (seperti halnya dalam nikah kontrak) dan harus dirahasiakan antara dirinya dengan Tuhan.

Adapun perbedaan antara jenis pernikahan tersebut dan nikah kontrak adalah bahwa yang terakhir menetapkan waktu yang disepakati, seperti sebulan atau dua bulan, setahun atau dua tahun. Ketika tiba waktunya, pernikahan menjadi batal. Inilah yang dinamakan nikah kontrak yag dilarang. Tidak dipandang bersalah seseorang yang menikah sesuai dengan al-Qur'an dan as-Sunnah sambil menyembunyikan niatnya untuk bercerai setelah habis masa kerja atau studinya di luar negeri. Niatnya bisa saja berubah karena niat tersebut tidak pernah diungkapkan dan tidak dicantumkan dalam akad pernikahan. Niatnya hanya diketahui oleh dia dan Tuhan, sehingga ia tidak bisa disalahkan. Pernikahan semacam itu merupakan sarana untuk menghindarkan dirinya dari perzinaan dan kemesuman. Mayoritas ulama memegang pendapat ini, seperti yang dikatakan oleh pengarang al Mughni, Muwaffiq al din ibn Qudamah, semoga Tuhan merahmatinya (Baz, 1990: 29-30).

\section{Tentang perempuan yang mengemudikan mobil}

Pertanyaan: ketika situasi mendesak, apakah perempuan tidak diperbolehkan mengemudikan mobil sendirian, tanpa ditemani laki-laki muhrimnya, dari pada harus naik mobil dengan seorang laki-laki yang bukan muhrimnya ${ }^{5}$ (misalnya naik taksi atau ditemani supir pribadi)? Semoga Tuhan memberkatimu dan membalas kebaikanmu. Fatwa:

\footnotetext{
${ }^{5}$ Ibn Rusyd (1989: 455 - 458) mengartikan Mahram adalah keluarga sedarah seperti saudara laki-laki atau anak laki-laki yang tidak boleh dinikahi oleh seorang perempuan.
} 


\section{Iman Fadilah}

seorang perempuan tidak diperbolehkan mengemudikan mobil karena dengan begitu ia harus membuka wajahnya atau bagian dari wajahnya itu. Di samping itu jika mobilnya mengalami kerusakan di jalanan, jika ia mengalami kecelakaan, jika ia ditilang, ia terpaksa harus berbaur dengan laki-laki. Lebih jauh lagi mengemudikan mobil memungkinkan perempuan bepergian jauh dari rumahnya dan jauh dari pengawasan walinya. Perempuan adalah makhluk yang lemah dan cenderung mengikuti emosi dan kehendak hatinya yang tak bermoral. Jika mereka diperbolehkan mengemudikan mobil, maka mereka akan terlepas dari pengamatan dan pengawasan yang semestinya dan perlindungan lakilaki dari lingkungan keluarganya, juga untuk mendapatkan hak mengemudi, perempuan harus mengajukan permohonan memperoleh surat ijin dan harus diambil gambarnya, mengambil gambar seorang perempuan dalam situasi demikian sekalipun, tidak dibenarkan karena hal tersebut dapat menimbulkan fitnah dan kerugian besar.

\section{Tentang Larangan Melakukan Ziarah Kubur bagi Perempuan}

Pertanyaan: apa hukum perempuan yang berkunjung ke makam Nabi (saw) dan apa hukum perempuan yag melakukan ziarah kubur dan apa dalilnya?

Fatwa: perempuan dilarang melakukan ziarah kubur. Sebenarnya, hal tersebut merupakan salah satu dosa besar, karena Nabi saw pernah bersabda, "Semoga Tuhan melaknat perempuan yang melakukan ziarah kubur, atau mereka yang mendirikan Masjid atau bangunan di atas kuburan." hal itu karena perempuan memiliki kekurangan akal, dan berwatak emosional sehingga mudah terbawa emosi. Jika perempuan mengunjungi, akan terjadi hal-hal yang merugikan. Jika perempuan mengunjungi makam, maka karena emosi dan kelemahannya, kunjungan tersebut akan sering dilakukan dan makam akan dipenuhi dengan kau perempuan. Jika iu terjadi, kompleks pemakaman akan 


\section{Iman Fadilah}

menjadi tempat orang-orang yang tak bermoral mencari perempuan. Lokasi pemakaman seringkali jauh dari hunian penduduk sehingga pasti akan menimbulkan keburukan yang sangat besar. Itulah sebabnya mengapa (kita harus menyadari bahwa) kecaman Nabi SAW, yang diarahkan kepada perempuan yang mengunjungi makam, didasarkan alasan yang sangat kuat. Namun jika seorang perempuan melewati makam, secara kebetulan dan bukan sebagai kunjungan yang direncanakan, ia boleh berhenti sejenak untuk mengucapkan salam. Salam tersebut diucapkan karena Aisyah pernah bertanya kepada nabi saw tentang apa yang harus diucapakan seorang muslim ketika mereka melewati kuburan dan beliau menasehatinya agar mengucapkan doa sebagai berikut "salam sejahtera pada kalian, wahai orang-orang Islam insya Allah kami akan segera menyusul kalian". Namun perempuan dilarang melakukan ziarah kubur dengan sengaja dan hal tersebut merupakan dosa besar.

\section{Tentang membuka hijab karena alasan medis}

Pertanyaan: saya menderita sakit dikulit kepala saya. Dokter menyuruh saya membuka hijab yang saya pakai untuk menutup kepala. Apakah saya boleh membukanya?Apa yang harus saya lakukan?

Fatwa: orang yang membuka hijab karena alasan medis diperbolehkan selama tidak ada orang asing bersama anda, misalnya (diperbolehkan) jika bersama suami. Anda juga diperbolehkan membukanya jika anda bersama anggota keluarga lainnya yang termasuk mahram anda, atau ketika bersama perempuan lain, selama suami mereka tidak bersama mereka. Namun jika anda pergi ke Pasar yang banyak laki-laki dan bukan mahram berkumpul di sana, anda wajib menutup kepala, wajah dan bagian tubuh lainnya (Utsaymin, 1990: 871-872). 


\section{Iman Fadilah}

\section{Tentang perempuan yang menjadi penghuni neraka terbanyak}

Pertanyaan: Apakah benar bahwa perempuan merupakan penghuni neraka terbanyak?apa sebabnya? Fatwa: Benar. Nabi Saw pernah berkata kepada sekelompok perempuan, "Wahai perempuan, banyaklah beramal, karena kalian akan menjadi penghuni neraka terbanyak. Pertanyaan serupa juga diajukan kepada Nabi Saw, (di riwayatkan, bahwa sekelompok perempuan itu) bertanya,"mengapa demikian wahai Nabi?", beliau menjawab."karena kalian sangat suka mengutuk dan tidak bersyukur kepada pasangan kalian (suami kalian).

Berdasar hadits di atas, CRLO berkesimpulan bahwa, mengapa banyak sekali perempuan masuk neraka, karena perempuan suka mengutuk, mencela dan mengumpat, dan tidak bersyukur pada pasangannya, yaitu suaminya.

\section{Tentang larangan foto}

Pertanyaan: Jika saya tinggal di luar negeri dan ingin mengirim foto saya kepada keluarga, teman dan terutama istri saya, apakah hal tersebut diperbolehkan atau tidak?

Fatwa: Hadits autentik dari Nabi Saw telah menetapkan larangan larangan terhadap lukisan segala sesuatu yang bernyawa, baik manusia atau bukan. Jadi anda tidak boleh mengirim foto anda baik kepada keluarga atau kepada istri anda. Fatwa ini dikeluarkan oleh komite CRLO dalam fatawa al Lajnah, jilid pertama (457-458). Dalam pandangan CRLO dengan merujuk pada hadts Nabi tersebut, segala bentuk gambar atau lukisan termasuk foto di dalamnya tidak diperbolehkan.

\section{c. Pemikiran Khaled Abou El Fadl dan Kritik Terhadap CRLO}

Dalam pemikiran Hukum Islam, Khaled Abou El Fadl atau El Fadl sangat berpengaruh dan menjadi ikon intelektual muslim secara umum. Karena kiprah dan ide-ide briliannya, ia dikagumi dan dieluk-elukan 


\section{Iman Fadilah}

oleh banyak kalangan. Selain itu, El Fadl adalah seorang Sarjana, Dosen dan Guru Besar Hukum Islam di Fakultas Hukum, Universitas California, Los Angeles (UCLA), Amerika Serikat, tempat ia mengajar Hukum Islam, hukum imigrasi, hak asasi manusia, hukum keamanan nasional dan internasional.

El Fadl dikenal sebagai kritikus keras terhadap kelompok Islam kanan atau golongan fundamentalis Islam. Di tengah-tengah kesibukannya, ia sering diundang ke seminar, simposium, lokakarya dan talk show di televisi dan radio baik nasional maupun internasional di Amerika seperti CNN, NBC, PBS, NPR, and the Voice of America (VOA). Dan belakangan ia banyak memberikan komentar tentang isu otoritas, terorisme, toleransi dan hukum Islam. Ia bekerja sebagai Dewan Direktur Pemantau Hak Asasi Manusia, dan juga bekerja sama dengan Komite Hakim untuk Hak Asasi Manusia.

\section{d. Kritik Abou El Fadl terhadap Fatwa CRLO Arab Saudi}

Dari beberapa fatwa yang dikeluarkan oleh CRLO, El Fadl merasa fatwa tersebut tidak berorientasi pada kemaslahatan umat. Bagaimanapun, fatwa tersebut merupakan refleksi dari ulama yang punya otoritas, dan seyogyanya lebih menekankan pada kondisi dan kebutuhan umat manusia. Kesan tekstualisme yang ditampilkan oleh CRLO menandai bahwa kumpulan fatwa masih terjebak pada keputusan formal teks, belum sepenuhnya mengakomodir kebutuhan dan perubahan masyarakat. Fatwa yang dikeluarkan cenderung diskriminatif dan tidak sesuai dengan tujuan awal hukum Islam. Semakin El Fadl mengkaji dan memikirkan fatwa tersebut, semakin ia merasa bahwa fatwa tersebut harus dikaji ulang, untuk menghilangkan kesan kekakuan atau otoriter pada fiqh. ${ }^{6}$ Bagaimanapun, fatwa yang dikeluarkan oleh CRLO dijadikan landasan hukum dalam fiqh

\footnotetext{
${ }^{6}$ Kaled El Fadl, 2001, And God Knows the soldier, Jakarta: Serambi.
} 


\section{Iman Fadilah}

keseharian di Arab Saudi. Dalam pandangan El Fadl, penetapan fatwa oleh CRLO masih merujuk pada teks-teks otoritatif semata, sementara aspek-aspek lain belum terangkum semisal, kejujuran (honesty), kesungguhan (dillegence), pengendalian diri (self restraint), memepertimbangkan berbagai aspek yang terkait (comprehensiveness) dan mendahulukan tindakan yang masuk akal (reasonableness). Beberapa aspek di atas menurut El Fadl seharusnya adalah bagian yang dipertimbangakan dalam menetapkan fatwa. Apa yang dilakukan CRLO lewat fatwanya adalah sebuah kesemena-menaan yang absolut (otoriter despotik) dan sekaligus penyelewengan (corruption) yang nyata terhadap teks Tuhan.

Beberapa fatwa yang menurut El Fadl perlu mendapat sorotan, antara lain: kasus tentang bra perempuan, sepatu bertumit tinggi dan perjanjian pernikahan bagi perempuan, fitnah yang timbul dari praktek ziarah kubur bagi perempuan, bahaya bagi perempuan yang bepergian tanpa mahram, perempuan dan setan dalam mobil (pelarangan perempuan mengendarai mobil sendiri), sujud pada suami, riwayat tentang tulang rusuk yang bengkok, kecerdasan di bawah standar, pembawa sial, anjing dan perempuan, salat di dalam lemari, merapat ke dinding dan bahaya godaan perempuan, (tubuh perempuan adalah aurat dan menimbulkan fitnah (godaan seksual) maka harus ditutupi atau dihijab), rasisme, seksisme, dan rasa keindahan. ${ }^{7}$ Ada dua alasan mengapa El Fadl menganalisis fatwa tersebut. Pertama: bahwa produk intelektual para ahli hukum dari CRLO melambangkan bentuk interpretasi yang bersifat otoriter. Kedua, para ahli CRLO mayoritas adalah bermazhab wahabi, yakni madzhab yang dalam penafsirannya lebih menekankan pada tekstualisme. Dan dewasa ini Wahabi menjadi mazhab yang dominan di dunia Islam. Pemahaman tekstual ini telah

${ }^{7}$ El Fadl, 2004 hlm 258-367 


\section{Iman Fadilah}

dicangkokkan ke dalam berbagai mazhab yang secara ideologis berseberangan dengan paham Wahabi, seperti mazhab pemikiran sufi. Semisal, pemikiran sufi Nuh Ha Min Keller atau Hisyam al-Kabbani.

Ciri metodologi mazhab Wahabi adalah semua persoalan hukum yang ditetapkan menghasilkan ketetapan yang pasti dan tunggal. Dalam penetapan fatwanya CRLO, memulai mencari hukum dari sumbersumber utama yakni al Qur'an dan Hadits kemudian di teliti, dicari, dan dinyatakan hukumnya dengan jelas dan berlaku sepanjang masa (Baz, 1990: 31). Inilah wujud dari praktek yang oleh El Fadl disebut otoritarianisme yang nyata yang dilakukan CRLO dengan fatwafatwanya. Dan ini pulalah yang mendasari kegelisahan El Fadl sebagai kritik terhadap fatwa yang diskriminatif dan menyimpang. Keberpihakan dan pembelaan El Fadl terhadap ketidakadilan penafsiran dan otoritarianisme dalam Hukum Islam sangatlah jelas. Dalam analisinya El Fadl mengurai beberapa fatwa yang dianggap kontroversial dan tidak berorientasi pada kemaslahatan. Sebagaimana disebut di awal, beberapa fatwa tersebut adalah:

1. Kasus Tentang Bra, Sepatu bertumit tinggi dan Perjanjian Pernikahan.

Seorang wakil khusus CRLO (orang yang punya otoritas mengeluarkan fatwa hukum), Syaykh Ibn Jibrin, ketika ditanya apakah menggunakan bra diperbolehkan menurut hukum Islam? Ibn Jibrin menjawab bahwa beberapa perempuan membiasakan diri menggunakan pakaian tambahan (bra) untuk memberikan kesan bahwa mereka masih muda atau perawan, dan jika memang demikian motifnya maka hal tersebut dipandang sebagai bentuk penipuan yang dilarang. Namun jika seorang perempuan yang memakai bra bertujuan untuk kesehatan dan pengobatan, maka hal tersebut di perbolehkan (Jibrin, tt.: 205). Tampaknya jika bra dipakai untuk mengangkat buah 


\section{Iman Fadilah}

dada atau payudara, dan motif dibalik pemakaian bra untuk menipu orang lain, maka hal tersebut dilarang. Yang dipersoalkan oleh mufti CRLO adalah penipuan karena memakai bra. Penipuan yang dimaksud adalah, ketika memakai bra, maka akan menambah keindahan tubuh dan ini masuk kategori curang atau menipu dari keadaan yang sesungguhnya. Dalam pandangan El Fadl, apa yang di fatwakan oleh CRLO setidaknya bisa di urai dari beberapa aspek. Pertama: dalil atau nash yang di pakai oleh CRLO tidak sesuai. Hadits yang dijadikan argumen yakni "siapapun yang berlaku curang bukanlah kelompok kami" Nabi tidak sedang berbicara masalah bra. Akan tetapi, hadits tersebut asbabun nuzulnya adalah Nabi SAW menemukan seorang pedagang yang berlaku curang dalam menjajakan barang dagangannya, kemudian beliau menyatakan bahwa bentuk pengelabuan dalam menjajakan barang dagangan dipandang sebagai perilaku yang tidak bisa diterima.

Menurut El Fadl, Ibn Jibrin tidak mengutip dalil al-Qur'an atau hadits secara spesifik tentang bra atau jenis pakaian lainnya. Ia juga tidak menyebutkan dalil atau nash tentang serban yang membuat seseorang terlihat lebih tinggi, baju yang membuat seseorang lebih berotot, atau pakaian yang membuat seseorang lebih ramping. Sementara penipuan pada dasarnya dilarang. Tapi menurut El Fadl, seorang ahli hukum harus menelusuri seluruh dampak dari argumentasinya. Dalam pandangan El Fadl, yang lebih penting adalah bahwa fatwa tersebut mempertimbangkan kebutuhan dan kemaslahatan bagi perempuan, akan tetapi nampaknya dalil CRLO tidak argumentatif sehingga faktor-faktor lain tidak menjadi pertimbangan dalam fatwa. Apalagi, kalau pemakaian bra untuk kesehatan, dengan sendirinya fatwa ini menjadi tidak kontekstual (El Fadl, 2003: 259). Hal yang sama juga terjadi pada fatwa tentang boleh tidaknya perempuan 


\section{Iman Fadilah}

memakai sepatu bertumit tinggi. Fatwa tersebut dikeluarkan CRLO, Syaykh Ibnu Baz dan Syaykh al-Utsaymin. Mereka berpendapat bahwa "sepatu bertumit tinggi tidak diperbolehkan dalam Islam". Alasan pelarangannya adalah, bahwa sepatu seperti itu tidak menyehatkan dan berbahaya bagi perempuan, karena bisa menyebabkan seorang perempuan bisa terkilir dan jatuh. Selain itu, sepatu tersebut juga menipu karena menjadikan perempuan terlihat lebih tinggi dan dapat menimbulkan fitnah karena akan menonjolkan paha perempuan (Baz, 1990: 294).

Menurut El Fadl yang jadi persoalan di sini adalah dasar penetapan hukum tersebut terkait dengan soal penipuan, basis penetapannya sama dengan fatwa tentang bra, yakni perempuan dipandang sebagi sumber fitnah (daya tarik seksual), sehingga segala sesuatu yang terkait dengan fungsi tubuh perempuan akan dipandang dari perspektif tersebut. Argumentasi yang dibangun oleh CRLO dalam perspektif El Fadl sama sekali tidak berdasar pada tujuan syari'at Islam yakni kemaslahatan bukan kesukaran. Soal legalitas tentang pernikahan misyar, model pernikahan yang populer di Arab di mana seorang laki-laki menikahi seorang perempuan dengan niat akan menceraikan setelah beberapa lama, tapi tanpa memberitahukan niat tersebut pada calon istrinya. Ibn Baz, CRLO, menetapkan bahwa pernikahan tersebut dipandang sah dan sama sekali tidak mengecam pihak laki-laki atas perilakunya yang curang.

Dari paparan di atas, dalam pandangan El Fadl, jika kontrak pernikahan yang bersifat sementara itu dinyatakan secara eksplisit dan disepakati bersama maka nikahnya sah. Tapi, jika niat untuk mengakhiri pernikahan setelah jangka waktu tertentu sengaja disembunyikan, maka pernikahan tersebut dipandang tidak sah. Menurut El Fadl, dalam fatwa tersebut telah terjadi pelegalan bagi laki- 


\section{Iman Fadilah}

laki untuk menguasai perempuan yang dibungkus melalui penafsiran teks yang sepihak. Dan hal ini akan mengakibatkan semakin dominannya laki-laki untuk menguasai perempuan dengan seenaknya. Ketetapan ini adalah bias jender dan tidak adil bagi perempuan. Rupanya menurut El Fadl mereka keliru dalam memahami pendapat beberapa ahli hukum mazhab Hambali tentang masalah ini, yang menyatakan bahwa, jika salah satu pihak saja yang berniat melanggengkan ikatan pernikahan, sedangkan pihak lainnya mempunyai niat tersembunyi untuk melangsungkan pernikahan yang hanya bersifat sementara, maka pernikahan tersebut masih dipandang sah. Para ahli hukum Hambali berpendapat bahwa, motif yang tidak benar dari salah satu pihak tidak serta-merta membatalkan pernikahan, dan mereka tidak mengatakan bahwa salah satu pihak dibenarkan atau diperbolehkan memiliki motif pengelabuan dalam urusan pernikahan.

Namun yang menarik adalah bahwa mayoritas ahli hukum mazhab Maliki dan Hambali, berpendapat bahwa niat melangsungkan pernikahan temporer baik diungkap maupun tidak oleh salah satu pihak dapat menyebabkan batalnya pernikahan. Tapi menurut mayoritas ahli hukum mazhab Hanafi dan Syafi'i bahwa niat untuk melangsungkan pernikahan temporer dari salah satu pihak, jika tidak diungkapkan, dipandang sebagai sebuah dosa, tapi tidak membatalkan pernikahan. Rupanya menurut El Fadl, mereka dalam mengeluarkan fatwa tersebut memperlihatkan kurangnya bentuk pengendalian diri, kesungguhan, dan rasionalitas. Akibatnya, satu-satunya suara yang muncul dalam fatwa tersebut adalah suara penafsir yang secara semena-mena telah memberi fatwa (El Fadl, 2004: 263).

\section{Fitnah yang timbul dari Praktek Ziarah Kubur bagi Perempuan}

Ketika beberapa ahli CRLO dimintai pendapatnya tentang, apakah seorang muslim perempuan diperbolehkan menziarahi makam 


\section{Iman Fadilah}

saudaranya, makam suaminya termasuk makannya Nabi? Jawaban para ahli hukum bersifat tegas. Mereka menetapkan "bahwa laki-laki muslim diperbolehkan melakukan ziarah kubur, bahkan sangat dianjurkan, namun hal itu terlarang bagi perempuan" (al Utsaymin, t.t, : 170). Dasar ketetapan mereka dinisbatkan pada hadits Nabi yang mengatakan bahwa, "Berziarahlah, karena sesungguhnya hal itu akan mengingatkanmu pada hari akhir" (Munawir, 2007: 185). Namun ketentuan hadits itu menurut CRLO tidak berlaku bagi perempuan. Mereka menegaskan bahwa Nabi pernah bersabda "Semoga Tuhan melaknat perempuan yang melakukan ziarah kubur" (al Halqat, t.t.: 131). Kemudian mereka mengemukakan alasan spekulatif pelarangan tersebut, bahwa perempuan adalah makhluk yang lemah secara intelektual dan emosional, juga rapuh secara psikologis. Jika mereka melakukan ziarah, mereka cenderung melakukan tindakan yang terlarang, seperti berteriak, meratap, dan memukul-mukul dada karena kesedihan mereka (Utsaymin, tt: 171).

Kelemahan fatwa ini menurut El Fadl adalah: bahwa mereka mendasarkan penetapannya pada pendapat yang menyatakan bahwa ziarah kubur bagi kaum perempuan adalah praktek yang dilarang, sementara pendapat jumhur yang menyatakan bahwa, pada mulanya praktek ziarah dilarang bagi laki-laki maupun perempuan, tapi kemudian diperbolehkan baik untuk laki-laki maupun perempuan, ini tidak ditampilkan oleh CRLO dalam fatwanya. Artinya, fatwa CRLO tentang larangan ziarah kubur bagi perempuan dasarnya tidak jelas, bahkan CRLO tidak seimbang dalam pengambilan dalil atau nash.

\section{Setan Dalam Mobil dan Bahaya Perempuan Yang Bepergian Tanpa} Mahram

Seorang mufti, Ibn Baz dari CRLO mengeluarkan fatwa tentang apakah seorang perempuan dibenarkan melakukan perjalanan sendiri 


\section{Iman Fadilah}

tanpa didampingi mahramnya, baik perjalanan tersebut untuk kepentingan pribadi atau untuk menunaikan ibadah haji. Dalam konteks tersebut, seorang perempuan bertanya jika suaminya kecelakaan, dan ia diminta untuk menjenguknya, apakah ia boleh pergi sendirian tanpa ditemani famili laki-lakinya selama dalam perjalanan? Dalam kondisi apapun seseorang perempuan tidak dibenarkan melakukan perjalanan lebih dari delapan puluh kilo meter (dua dhiro'). Ketetapan tersebut didasarkan atas hadits yang dinisbatkan pada nabi yang berbunyi "Tidak dibenarkan bagi seseorang perempuan yang beriman untuk bepergian sejauh satu hari perjalanan tanpa di temani mahram" (Ibn Baz, 1990: 351-355). Ibn Fawzan dari CRLO secara khusus memberi penjelasan bahwa larangan tersebut penting, karena pesawat, mobil atau kereta yang ditumpanginya bisa saja mengalami masalah sehingga si perempuan itu akan terlantar sendirian tanpa seorang pelindung. Di samping itu perempuan tersebut kemungkinan bisa mendatangkan fitnah, maka perempuan sebaiknya tidak bepergian jauh tanpa ditemani mahramnya.

Dalam analisisnya, El Fadl menilai sebab operatifnya (illah) adanya keharusan mahram adalah karena faktor keamanan yang tidak terjamin. Oleh karena itu dalam konteks sekarang, jika keamanan perjalanan bisa dijamin dengan berbagai sarana, maka seorang perempuan boleh bepergian sendirian atau bersama perempuan lainnya. Di sinilah kelemahan fatwa CRLO terletak (El Fadl, 2004: 272). Apalagi, fatwa yang dikeluarkan Ibn Baz dan Ibn Fawzan selanjutnya menjadi hukum resmi Arab Saudi.

\section{Sujud pada Suami sebagai Ketundukan Istri pada Suami.}

Shalih ibn Fawzan (tt: 262) dari CRLO, dalam al muntaqa, mengeluarkan fatwa bahwa, seorang istri dituntut untuk mematuhi suaminya, selama perintah suaminya itu bisa dibenarkan. Hal tersebut 


\section{Iman Fadilah}

berarti bahwa seorang istri harus mematuhi suaminya jika ia memerintahkan untuk tidak meninggalkan rumah, tidak bekerja di luar rumah, dan tidak mengunjungi teman-temannya. Dengan kata lain, seorang istri harus mematuhi suaminya dalam semua urusan duniawi. Jika seorang suami mengajak istrinya ke tempat tidur (berhubungan seksual), maka ia harus segera melayaninya, dan tidak boleh menolak sebab jika ia menolak ia akan dilaknat oleh malaikat mulai malam sampai pagi harinya. Dan jika seorang istri berniat puasa di luar bulan Ramadhan, ia harus mendapat izin dari suaminya ( Fawzan, t.t.,: 263). Mufti mendasarkan penetapannya pada al-Qur'an yang menyatakan bahwa "kaum laki-laki adalah sebagai pemimpin (qawwamun) bagi kaum perempuan, karena Allah telah melebihkan sebagian mereka atas sebagian yang lain, dan karena mereka telah menafkahkan sebagian dari harta mereka " (QS an Nisa: 34). Dan biasanya bagi orang yang setuju dengan CRLO menjadikan ayat tersebut sebagai legitimasi tambahan bahwa seorang suami berhak menyuruh dan mendisiplinkan istrinya. Di samping itu ketetapan tersebut juga di dasarkan pada hadits yang menyatakan bahwa nabi pernah bersabda, "Seseorang tidak dibenarkan untuk sujud kepada siapapun. Tapi sekiranya saya harus menyuruh seseorang untuk bersujud kepada seseorang lainnya, maka saya akan menyuruh seorang istri untuk bersujud pada suaminya, karena begitu besarnya hak suami terhadap istrinya," (Abu Dawud, alTirmidzi, Ibn Majah)

Dalam versi lain yang diriwayatkan oleh Azhar Ibn Marwan. Azhar meriwayatkan ketika Mu'adz kembali dari Syam, ia bersujud pada Nabi. Nabi berkata, apa yang kau lakukan Muadz? Muadz menjawab, saya baru datang dari Syam dan saya melihat penduduk di sana bersujud pada pendeta dan orang-orang suci, dan saya juga ingin melakukan hal yang sama kepadamu," Nabi berkata,"jika saya harus 


\section{Iman Fadilah}

menyuruh seseorang untuk bersujud kepada selain Allah, saya akan menyuruh seorang istri bersujud pada suaminya, demi Allah seorang istri belum dipandang telah memenuhi kewajibannya kepada Allah hingga ia memenuhi kewajibannya kepada suaminya, dan jika ia diminta melayani suaminya (hubungan seks) ketika ia berada di atas unta, maka ia tidak boleh menolak permintaan suaminya" (HR Azhar ibn Marwan). Dalam pandangan El Fadl, penetapan di atas problematis, selain soal pemahaman teks yang masih tidak mendalam (tekstual), sisi lain tidak mempertimbangkan adanya penafsiran lain. Hadits yang di jadikan sandaran penetapan tersebut masih dipertanyakan legalitasnya. Apa betul nabi memerintahkan istri untuk bersujud pada suami, bahkan juga harus melayani hubungan seks di atas unta sekalipun jika diminta.

\section{e. Aplikasi Hermeunitika Khaled Abou El Fadl}

Bagi banyak kalangan, kajian kritis keagamaan lewat pendekatan hermeneutik tidak begitu populer dan untuk kalangan tertentu justru cenderung dihindari. Jangankan menggunakan dan menerapkannya dalam kajian-kajian akademik tentang kehidupan sosial keagamaan, mendengar istilah hermeneutik pun bagi sebagian orang sudah antipati. Macam-macam konotasi yang diletakkan orang terhadap hermeneutik. Yang mudah diingat adalah predikat relativisme, atau istilah populer yang digunakan di tanah air belakangan ini adalah pendangkalan akidah. Sebagian lain dikaitkan dengan pengaruh kajian biblical studies di lingkungan kristen yang hendak diterapkan dalam kajian al-Qur'an di lingkungan Islam.

El Fadl hendak menyatakan bahwa pemahaman tentang hermeneutik sebenarnya tidaklah seperti itu. Pertanyaaan pokok dalam hermeneutik adalah bagaimana sesungguhnya hubungan teks (text) atau nash, penulis atau pengarang (author) dan pembaca (reader) 


\section{Iman Fadilah}

dalam dinamika pergumulan pemikiran hukum Islam. El Fadl menyoroti bagaimana mekanisme perumusan dan pengambilan keputusan fatwa-fatwa yang dikeluarkan baik oleh pribadi-pribadi, tokoh-tokoh masyarakat dan lebih-lebih lembaga-lembagaa dan organisasi keagamaan pada umumnya.

Kompetensi dasar seperti apa yang sesungguhnya dimiliki oleh seseorang, kelompok, organisasi atau istitusi-institusi keagamaan yang berani mengatas-namakan diri atau lembaganya sebagai pemegang tunggal penafsir dan sekaligus pelaksana perintah Tuhan? Alat uji shahih seperti apa yang diperlukan untuk mengetes atau menguji validitas klaim otoritas ketuhanan yang melekat dalam fatwa-fatwa keagamaan? Mengapa dalam dunia praksis keagamaan, tiba-tiba muncul fenomena umum yang disebut otoritarianisme atau lebih tepat disebut menggunakan kekuasaan Tuhan (author) untuk membenarkan tindakan sewenang-wenang pembaca (reader) dalam memahami dan menginterpretasikan teks (text).

Satu hal yang tidak dapat dihindari oleh siapapun adalah suatu kenyataan bahwa perintah-perintah Tuhan (divine instruction) selalu bertumpu pada "teks" (kitabah; qawliyyah), sedang teks itu sendiri sepenuhnya bersandar pada alat perantara "bahasa" (lughah). Bahasa inilah yang menjadi sumber silang pendapat sepanjang masa, karena ia tidak lain adalah hasil kesepakatan komunitas dan ciptaan budaya manusia. Huruf, kata, kalimat, kata sifat sangat tergantung pada sistem simbol. Sedang simbol itu sendiri memerlukan bantuan dan dukungan asosiasi-asosiasi tertentu, gambaran-gambaran, juga emosi para pendengar, sangat bisa jadi berubah dari waktu ke waktu. Dengan begitu, tampaknya bahasa memiliki realitas objektif tersendiri, karena maknanya tidak dapat ditentukan secara efektif dan sepihak, baik oleh author (pengarang) maupun oleh pembaca (reader). Oleh karena 


\section{Iman Fadilah}

kompleksnya persoalan yang dihadapi oleh masyarakat penentu makna, maka pemahaman teks tidak bisa ditentukan oleh kelompok manapun. Ketika proses pemahaman teks yang sesungguhnya bersifat interpretatif (banyak pilihan makna dan penafsiran) ditutup (pintu ijtihad ditutup), maka seseorang atau kelompok telah memasuki wilayah tindakan yang bersifat sewenang-wenang (despotic).

Abou el Fadl secara komprehensif membedah fatwa keagamaan yang dikeluarkan oleh CLRO. El Fadl tidak saja berhasil menunjukkan kecenderungan berkuasanya hermeneutika despotik yang terwujud dalam otoritarianisme tekstual setelah menunggangi otoritas teks suci. El Fadl juga berhasil memberikan "proposal metodologis" yang berdasar pada ikhtiar untuk menghormati otoritas teks demi menyelamatkan diskursus dari perlakuan kelompok puritan yang semena-mena dan arogan.

Dua hal yang digaris bawahi oleh El Fadl untuk mengelak dari jebakan otoritarianisme ini adalah ketekunan dan pengendalian diri. Seseorang harus tekun dan cermat dalam mengerahkan segenap nalar dan daya selidiknya. Bobot beban kewajiban untuk tekun dan cermat ini sebanding dengan tingkat keseriusan implikasi sosial dan teologis dari persoalan atau teks yang dikaji. Di samping itu, seseorang juga harus mampu mengendalikan dirinya dengan menuturkan pelbagai alternatif perspektif yang ditemukan dan menyadari bahwa ada sejumlah pandangan lain yang memiliki hak untuk dikemukakan dan dijadikan pegangan.

Gagasan El Fadl yang cukup tajam juga adalah ketika dia mengaitkan hukum dan moralitas. Kritik El Fadl atas puritanisme adalah bahwa puritanisme menganut pandangan positivisme ekstrem, yang mengakui hukum positif sebagai nilai moral tertinggi dan mengabaikan pertimbangan-pertimbangan normatif lainnya. Padahal 


\section{Iman Fadilah}

bagi El Fadl, moralitas tidak membutuhkan otoritas tekstual untuk dapat diterapkan-moral adalah sesuatu yang inheren dalam sosok manusia itu sendiri. Karena itu, logika dan hukum-hukum moral tentang kebenaran, kebaikan juga perlu dikaji secara mendalam, sebab itu akan menjadi pemandu agar ajaran agama tetap bisa dijangkarkan kepada realitas kemanusiaan yang terus berubah. Perspektif inilah yang digunakan El Fadl ketika mengkritik ketidakcukupan pendekatan kepentingan publik (maslahah) dalam bidang ushul fiqh, dan perlu diangkatnya analisis matn dan logika substantif hadits.

Sederhananya, El Fadl menekankan pentingnya mengembalikan etos intelektual, etos keilmuwan yang pernah ada dalam sejarah umat Islam di tengah ramai atau riuhnya 'klaim' (pengakuan) banyak orang yang merasa paling tahu dan paling benar mengenai maksud Allah dan Nabi sampai-sampai mereka merasa sebagai satu-satunya orang yang paling 'mewakili' Allah dan Rasul, mereka lupa bahwa setiap orang diberikan mandat 'menjadi wakil Allah' (khalifah) di muka bumi. Dalam tradisi fiqh dikenal istilah badzlu wushu'i atau badzl qarihah atau pengerahan segala daya upaya dalam melakukan penafsiran ajaran agama.

Fase ini menggambarkan bahwa besarnya tanggung jawab seorang ulama dalam melakukan penalaran atas makna dari al-Qur'an ataupun Sunnah Nabi. Sebagus apapun hasil ijtihad mereka itu tidaklah mutlak. Sehebat apapun hasil ijtihad mereka itu tetaplah relatif dan tidak menggugurkan pendapat lainnya. Hasil memang bukan segalanya, kata El Fadl, tetapi semangat moral atau etos moral dibalik proses ijtihad tersebut seharusnya menginspirasi kita sebagai pewaris ilmu pengetahuan untuk bersikap terbuka dan toleran atas perbedaan.

Tanpa integritas, etos moral, dan kesungguhan seseorang yang menyelami makna al-Qur'an akan terjerumus pada sikap otoriter (sok 


\section{Iman Fadilah}

berwenang), yang mana kepentingan pribadinya akan mewarnai hasil pemahamannya. Contohnya, banyak pemakaian Hadits secara acak dan sembarangan oleh banyak kalangan untuk mendukung kepentingankepentingan mereka. Dikatakan acak karena hadits-hadits yang sedemikian banyak itu diambil begitu saja dari kitab-kitab hadits tanpa mau mengecek ulang tingkat riwayat, kategori matan, dan konsekwensi moral dan sosialnya jika diterapkan. Dari berbagai argumentsi di atas, ide terbesar El Fadl terhadap diskursus hukum Islam kontempoter adalah membongkar "malpraktik otoritarianisme" dalam hukum Islam.

Fenomena ini menurut El Fadl menjadi mainstream pemahaman umat Islam tehadap hukum Islam pada dewasa ini. Sehingga lahir wacana hukum Islam dan fiqh yang otoriter, tertutup dan statis. Padahal sejak dini, El Fadl ingin menunjukkan hukum Islam layak dipuji sebagai "jantung dan inti agama Islam", atau dalam istilah Joseph Schacht "puncak peradaban Islam" dan menurut Al-Jabiri "peradaban Islam adalah peradaban fiqh" karena fiqh memiliki kelenturan, keterbukaan, dan antiotoritarianisme. Idealnya diskurus hukum Islam bagi El Fadl adalah diskurus fiqh yang inklusif, toleran dan progresif. Obsesi El Fadl adalah mengembalikan syariat Islam dalam diskursus fiqh yang mengalami keragaman, penyegaran, pembaruan dan progresif. Bagaimana trik-trik El Fadl tersebut? Paling tidak beberapa poin di bawah ini bisa mewakilinya.

Pertama, El Fadl memandang al-Quran dan Sunnah sumber otoritatif hukum Islam sebagai "teks yang terbuka" maka konsekuensi logisnya adalah meyakini hukum Islam sebagai karya yang terus berubah (Islamic law as a work in movement). Untuk itu teks-teks otoritatif sebagai sumber dari hukum Islam tidak boleh dikunci, ditutup dan dipasung sehingga meniscayakan penafsiran dan pemahaman baru akan terus-menerus lahir. Teks yang terbuka akan mampu menampung 


\section{Iman Fadilah}

gerak dinamis pemahaman manusia dengan keragaman konteksnya. Memasung makna teks merupakan tindakan kriminal sekaligus kesombongan intelektual karena telah mengklaim dirinya paling mengetahui maksud Tuhan. Selain itu sikap tersebut akan menutup rapat-rapat bagi lahirnya pemahaman-pemahaman (fiqh) baru yang menjadi kebanggaan umat Islam sepanjang sejarah.

Kedua, mengembalikan diskursus hukum Islam pada semangat awal, yaitu meneguhkan kembali ijtihad sebagai upaya pengerahan sekuat-kuatnya kemampuan manusia untuk melakukan pencarian, penyeledikan dan pemahaman terhadap Kehendak Tuhan. Dalam konteks ini El Fadl membedakan antara syariah dan fiqh. Syariah adalah Kehendak Tuhan dalam bentuk yang abstrak dan ideal, tapi fiqh merupakan upaya manusia memahami Kehendak Tuhan.

Dalam pengertian ini syariah selalu dipandang sebagai yang terbaik, adil dan seimbang. Sedangkan fiqh hanyalah upaya untuk mencapai cita-cita dan tujuan syariah (maqashid al-Syari'ah). Tujuan syariat Islam adalah mewujudkan kemaslahatan manusia (tahqiq mashalih al-'ibad) dan tujuan fiqh adalah untuk memahami dan menerapkan syariah. Perbedaan ini lahir dari pengakuan atas kegagalan upaya manusia untuk memahami tujuan dan maksud Tuhan. Dalam konteks ini ijtihad manusia tidak pernah final dan sempurna.

Ketiga revitalisasi metodologi hukum Islam klasik. Bagi El Fadl, hukum Islam secara kukuh menentang kodifikasi dan penyeragaman (Islamic law has staunchly resisted codification or uniformity). Metodologi hukum Islam memiliki ciri yang terbuka dan anti otoritarianisme (tradisional Islamic methodology has been its openended and anti-authoritarian character).

Namun yang menjadi persoalan dewasa ini adalah kecenderungan praktik hukum Islam yang memperlakukan syariat Islam sebagai 


\section{Iman Fadilah}

perangkat aturan (ahkâm) yang mapan, statis dan tertutup yang harus diterapkan tanpa menyisakan ruang yang luas untuk pengembangan dan keragaman. Singkatnya hukum Islam pada modern ini dipandang sebagai perangkat aturan (ahkâm) bukan sebagai sebuah proses pemahaman (fiqh). Kecenderungan yang berpotensi melahirkan otoritarianisme dalam memahami hukum Islam itu yang terus dilawan oleh El Fadl.

\section{Simpulan}

Pemikiran Khaled Abou el Fadl telah melihat mekanisme perumusan dan pengambilan keputusan fatwa-fatwa yang dikeluarkan baik oleh pribadi-pribadi, tokoh-tokoh masyarakat dan lebih-lebih lembaga-lembagaa dan organisasi keagamaan pada umumnya. Salah satu kritik Khaled Abou el Fadl tentang fiqh perempuan adalah kritik dari fatwa yang dikeluarkan oleh CRLO yang cenderung mendiskriminasikan perempuan dalam berbagai aktivitas kehidupannya. Dalam konteks tersebut, pada dasarnya hal yang terpenting untuk dipahami dalam hermeneutik adalah bagaimana sesungguhnya hubungang teks (text) atau nash, penulis atau pengarang (author) dan pembaca (reader) dalam dinamika pergumulan pemikiran hukum Islam. Dengan demikian hal yang diperlukan adalah fiqh yang humanis dan tidak diskriminatif terhadap perempuan. 


\section{Iman Fadilah}

\section{DAFTAR PUSTAKA}

El Fadl, Khaled, And God Knows the soldier: The Authoritative and Authoritarian in Islamic Discourse, terj. Kurniawan Abdullah, Jakarta: Serambi, 2001.

Conference of the book, the Search for Beauty in Islam, terj. Abdullah Ali, Jakarta: Serambi, 2002.

Islam and Challenge of Democracy terj.Ruslani, Jakarta: Serambi, 2003.

Rebbelion and Violence in Islamic law, 2001.

Speaking in God's Name: Islamic Law, Authority and Women, terj. Cecep Lukman, Jakarta: Serambi, 2003.

,The Great Theft, terj. Selamatkan Islam dari Muslim Puritan, Jakarta: Serambi, 2006.

Engineer, Asghar Ali, Islam dan Teologi Pembebasan, Yogyakarta: Pustaka Pelajar, 2003.

, on Developing Theology of Peace in Islam, terj. Rizqon Khamami, Liberalisasi Teologi Islam; Membangun Teologi Damai dalam Islam, Yogyakarta: Alenia, 2004.

Esack, Farid, Al-Quran, Liberalisme, Pluralisme: Membebaskan yang Tertindas, terj. Watung Budiman, Bandung: Mizan, 2000.

Farouq, Abu Zayd, Hukum Islam Antara Tradisionalis dan Modernis, Terj. Husein Muhammad, Jakarta; P3M, Cet.II, 1986.

Fathurrahman, dkk, Dasar-Dasar Pembinaan Fiqh, Bandung :al Ma'arif, 1986.

Fazlur Rahman, Islamic Methodology in History, terj. Anas Wahyudin, Bandung: Pustaka, 1995.

Mahmoud Thoha, Muhammad, The Second Message of Islam Terj. Nurrahman, Surabaya: eLSAD, 1996.

Majalah F?ilsafat Driyakarya, Jakarta, Memahami Teks, TH.XXV no. 2 


\section{Iman Fadilah}

Majid Asy-Syarafi, Abdul, Al-Ijtihad al-Jama'I Fi at-Tasyri' Al-Islami, Terj.Syamsuddin, Jakarta: Pustaka al-Kautsar, 1998.

Mu'alim, Amir dan Yusdani, Ijtihad Dan Legislasi Muslim Kontemporer, Yogjakarta: UII Press, 2002

Mudzhar, Atho, Fatwa-Fatwa Majlis Ulama Indonesia (Sebuah Studi tentang Pemikiran Hukum Islam di Indonesia Tahun 19751988), Jakarta: INIS, 1993.

Rahman, Fazlur, Islam And Modernity: Transformation of Intelectual Tradition, Chicago: Chicago University Press, 1980.

, Major themes of the Al-Qur'an, terj. Anas M, Bandung: Pustaka, 1996.

Watt, Montgomery, Bell's Introduction to the Al-Qur'an, terj Lilian D.T. Jakarta: INIS, 1998.

Weber, Max, Essays in Sosiology, terj. Noorkholis, Yogyakarta: Pustaka Pelajar, 2006.

Zuhri, Muhammad, 1997, Hukum Islam Dalam Lintasan Sejarah, Jakarta: PT. Raja Grafindo Persada, 1997. 